\title{
Analisis Dan Perancangan Software Pengukuran Kemiripan Kode Program
}

\author{
Diah Rahmadhita Islami ${ }^{1, *}$, Diaz Rizqi Aprilliando ${ }^{2}$, Ukhty Uswatun Hasanah ${ }^{3}$, Muhammad Ainul \\ Yaqin $^{4}$ \\ Jurusan Teknik Informatika, Universitas Islam Negeri Maulana Malik Ibrahim, Indonesia \\ ${ }^{1}$ mohammad1rahmadhita2000@gmail.com; 2diazrizqi14@gmail.com; ${ }^{3}$ uktyhasanah.24@ gmail.com; ${ }^{4}$ yaqinov@ ti.uin- \\ malang.ac.id; \\ *corresponding author
}

INFO ARTIKEL

\section{Sejarah Artikel}

Diterima: 23 Desember 2019

Direvisi: 16 April 2020

Diterbitkan: 30 Agustus 2020

Kata Kunci

K-means

Rabin Karp

Kemiripan

\section{ABSTRAK}

Penelitian ini bertujuan untuk menganalisis data untuk mengelompokkan data dengan karakteristik yang sama ke suatu wilayah yang sama dan data dengan karakteristik yang berbeda ke wilayah yang lain. Penelitian ini dibuat dengan menggunakan algoritma Rabin Karp dan metode $K$-Means. Penelitian ini akan dibuat dengan menganalisis dan perancangan software pengukuran kemiripan kode program hanya dengan menginputkan kode program yang akan di cek plagiarismenya kemudian diurutkan berdasarkan cluster yang memiliki karakteristik yang sama. Sehingga data dalam satu cluster memiliki tingkat plagiarisme yang maksimum dan data antar cluster memiliki kemiripan yang minimum. Hasil penilitian ini berupa data-data akan dibagi sesuai dengan cluster masing - masing.

\section{PENDAHULUAN}

Pada saat ini, tidak sedikit universitas di Indonesia yang membuka program studi Teknik Informatika. Di jurusan Teknik Informatika banyak terdapat mata kuliah tentang pemrograman komputer yang dilaksanakan oleh mahasiswa. mata kuliah pemrograman ini digunakan untuk mengasah logika para mahasiswa dalam memecahkan masalah. Pada umumnya di setiap mata kuliah pemrograman dosen atau tenaga pengajar akan mengecek plagiarism dari kode program yang sudah dibuat oleh mahasiswa, akan tetapi banyak dari dosen atau tenaga pengajar yang merasa kesulitan untuk mengidentifikasi plagiarisme yang terdapat pada kode program yang sudah dibuat[1]. Untuk mencari plagiarism yang terdapat pada kode program dibutuhkan kesabaran yang lebih. Meskipun dalam menemukan plagiarisme merupakan hal yang mungkin, akan tetapi hal tersebut memerlukan waktu yang cukup lama. Karena saat ini banyak dari mahasiswa yang lebih memperhitungkan tentang efektifitas dan efisiensi untuk mencapai tujuan yang diharapkan tanpa harus susah payah membuat kode program sendiri jadi banyak sekali ditemukan kasus tentang plagiarism yang ada pada kode program. Tindakan-tindakan yang dianggap sebagai plagiarisme terhadap kode program yaitu seperti mengambil kode program yang dimiliki orang lain pada bahasa pemrograman yang sama, seorang mahasiswa atau peneliti yang dengan sengaja menyuruh seseorang untuk membuatkan program yang dibutuhkan untuk menyelesaikan tugas pemrograman.

Menurut Burrow [2] pada metode pendeteksian ada dua kategori utama yaitu text-based dan code-based. Untuk sistem yang berbasis kode ada dua pendekatan yang digunakan, pendekatan itu adalah structure-oriented dan attribute-oriented. Untuk pengukuran program pada attribute-oriented code-based system kesamaan antara program diukur dengan 
banyaknya operand dan operator yang dipakai, namun cara ini punya keterbatasan yaitu cara ini hanya efektif jika program yang diperiksa sangat mirip sedangkan saat ini banyak sekali penjiplakan dengan menambah atau mengurangi kode program. Pada structure-oriented code-based system ini relatif tahan dengan perubahan-perubahan kecil yang terjadi pada code program contohnya seperti penambahan variabel, penambahan kode program dan lainnya, sehingga jika ingin menghindari penjiplakan maka harus mengubah sebagian besar dari kode program menjadi suatu representasi kemudian akan di deteksi kemiripan representasi kode program itu.

Ada beberapa perangkat lunak yang sudah dirancang untuk mendeteksi plagiat dalam kode program, contohnya adalah Moss, Jplag. Duplikasi kode program, pendeteksian plagiat, dan juga pencocokan string sudah banyak dibahas dari penelitian-penelitian yang lain. Dari penelitian tersebut digunakan algoritma Winnowing, Smith Waterman, Boyer Moore, dan Rabin Karp. Untuk penggunaan algoritma Rabin Karp menerapkan metode fingerprinting metode ini hanya membandingkan pola string saja, dan juga plagiat ini tidak memperhatikan penulisan sumber rujukan. Selain menggunakan algoritma Rabin Karp penelitian ini akan menggunakan clustering yaitu dengan metode $K$-means. Pada penelitian ini digunakan algoritma Rabin Karp karena algoritma Rabin Karp sangat efektif dan juga pada peningkatannya sangat signifikan dibandingkan algoritma lainnya.

\section{METODE}

\section{Plagiarisme}

Plagiarisme merupakan kegiatan penjiplakan atau pengambilan karya milik orang lain tanpa sepengetahuan orang yang bersangkutan. Plagiat dianggap sebagai tindak kriminal karena mengambil karya milik orang lain tanpa izin [2].

\section{Algoritma Rabin Karp}

Algoritma Rabin Karp merupakan algoritma yang dibangun oleh Michael O. Rabin dan Richard M. Karp, algoritma ini dibangun pada tahun 1987. Algoritma Rabin Karp merupakan algoritma yang dipakai untuk pencarian string dan algoritma ini memanfaatkan fungsi hashing yang digunakan untuk memperoleh pater di dalam string teks. Ada beberapa karakteristik yang terdapat pada algoritma Rabin Karp yaitu algoritma ini memanfaatkan KGram dan hashing. Algoritma Rabin Karp diterapkan setelah melalui tahapan atau proses preprocessing[3]. Pada algoritma Rabin Karp ada beberapa tahapan yaitu K-Gram. K-gram yaitu rangkaian token yang panjang, panjangnya yaitu $\mathrm{k}$. Pada metode ini penggunaanya dengan cara pengambilan potongan-potongan karakter huruf dengan jumlah nilai $\mathrm{k}$, potongan huruf itu diambil teks secara kontinuitas yang dibaca mulai awal teks sumber hingga akhir pada teks sumber. Berikut ini adalah contoh dari K-Gram dengan nilai k=1, contoh tersebut dapat dilihat pada Tabel 1.

Tabel 1. Contoh K-Gram

\begin{tabular}{|c|c|}
\hline Kalimat & Handphone adalah perangkat elektronik \\
\hline Processing & handphoneadalahperangkatelektronik \\
\hline $\operatorname{Gram}\{4\}$ & 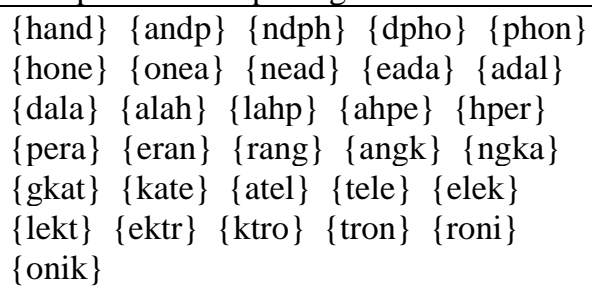 \\
\hline
\end{tabular}


Berikutnya adalah hashing. Hashing adalah metode yang digunakan untuk menemukan nilai hash, yaitu dengan cara mengganti karakter string ke integer. Pada proses tersebut menggunakan fungsi rolling hash, yang digunakan untuk mengubah string menjadi nilai hash. Pada persamaan rolling hash bisa dilihat pada Persamaan 1.

$$
\mathrm{H}\left(\mathrm{c}_{1 \ldots} \ldots \mathrm{c}_{\mathrm{k}}\right)=\left(\mathrm{c}_{1} * \mathrm{~b}^{(\mathrm{k}-1)}+\mathrm{c}_{2} * \mathrm{~b}^{(\mathrm{k}-2)}+\ldots+\mathrm{c}_{(\mathrm{k}-1)} * \mathrm{~b}^{\mathrm{k}}+\mathrm{c}_{\mathrm{k}}\right) \bmod \mathrm{q} \cdot[4]
$$

Keterangan :

$\mathrm{H}$ : substring

c : nilai ascii per-karakter

b : konstan bilangan prima

$\mathrm{k}$ : banyak karakter

q: modulo bilangan prima

Dibawah ini adalah contoh dari perhitungan rolling hash terhadap substring makan dengan nilai K-Gram 4 dapat dilihat pada Tabel 2.

Tabel 2. Contoh Hashing

\begin{tabular}{|c|c|}
\hline 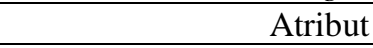 & Nilai Array \\
\hline Rolling hash pertama & $\begin{array}{l}{[0]=>\text { coba }} \\
c=99, o=111, b=98, a=97, \text { basis }=11, \bmod = \\
10007 \\
H=c \_c^{*} b^{\wedge}(k-1)+c \_0^{*} b^{\wedge}(k-2)+c \_b^{*} b^{\wedge}(k-3) \\
+c \_a^{*} b^{\wedge}(k-4) \\
H=99^{*} 11^{\wedge} 3+111^{*} 11^{\wedge} 2+98 * 11^{\wedge} 1+97 * 11^{\wedge} 0 \\
H=131769+13431+1078+97 \\
H=146375 \operatorname{Mod} 10007 \\
H=6277\end{array}$ \\
\hline Rolling hash kedua & $\begin{array}{l}{[1]=>\text { saja }} \\
\mathrm{s}=115, \mathrm{a}=97, \mathrm{j}=106, \mathrm{a}=97, \text { basis }=11, \bmod = \\
10007 \\
\mathrm{H}=\mathrm{c} \_\mathrm{s}^{*} \mathrm{~b}^{\wedge}(\mathrm{k}-1)+\mathrm{c} \_\mathrm{a}^{*} \mathrm{~b}^{\wedge}(\mathrm{k}-2)+\mathrm{c} \_\mathrm{j}^{*} \mathrm{~b}^{\wedge}(\mathrm{k}-3) \\
+\mathrm{c} \_\mathrm{a}^{*} \mathrm{~b}^{\wedge}(\mathrm{k}-4) \\
\mathrm{H}=115^{*} 11^{\wedge} 3+97 * 11^{\wedge} 2+106^{*} 11^{\wedge} 1+97^{*} 11^{\wedge} 0 \\
\mathrm{H}=153065+11737+1166+97 \\
\mathrm{H}=166065 \mathrm{Mod} 10007 \\
\mathrm{H}=5953\end{array}$ \\
\hline
\end{tabular}

Jika algoritma Rabin-Karp ditulis ke dalam pseudocode:[5], seperti ditunjukkan pada Gambar 1.

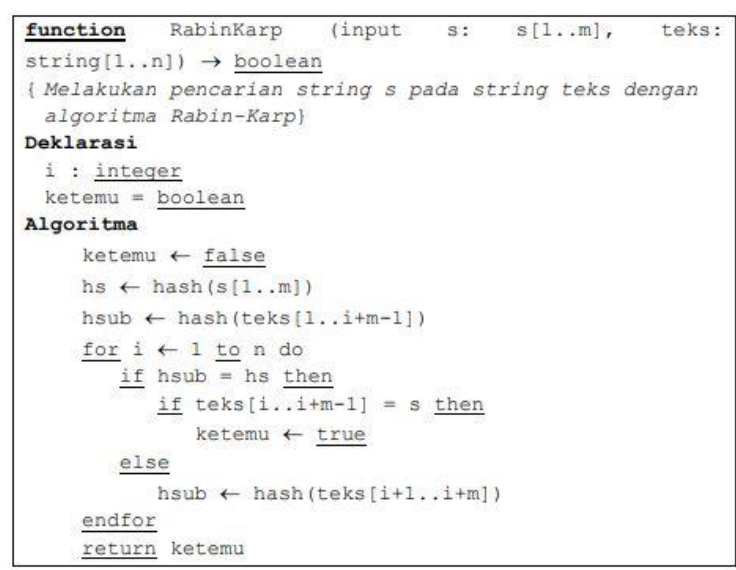

Gambar 1. Pseudocode Algoritma Rabin-Karp 


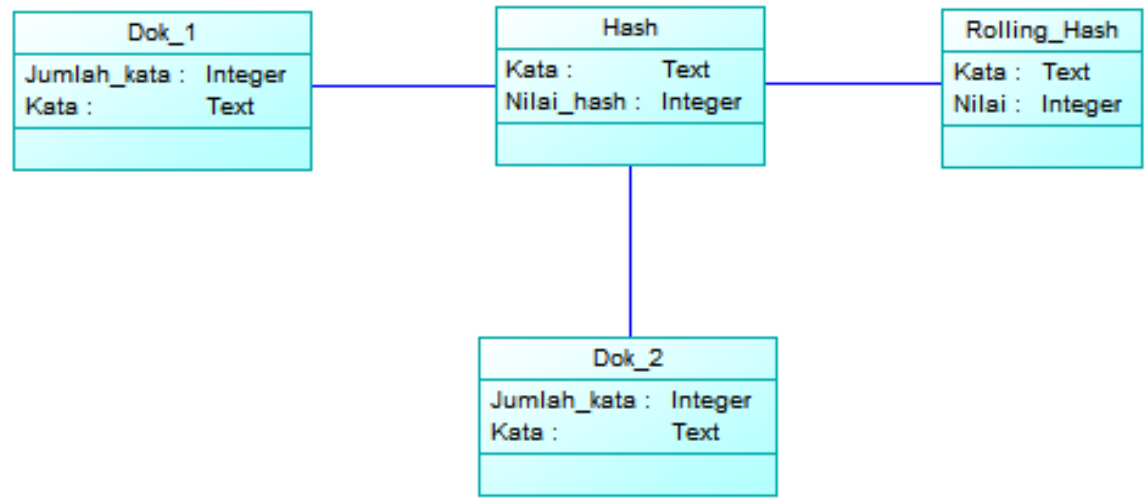

Gambar 2. Class Diagram dari algoritma rabin karp

\section{Clustering}

Clustering atau yang bisa disebut dengan klasterisasi adalah metode pengumpulan data atau yang dapat diartikan sebagai sebuah proses partisi satu set objek data kedalam cluster, cluster disini mempunyai kemiripan karakteristik antar satu sama lain dan berbeda dengan cluster yang lain, partisi ini dilakukan dengan suatu algoritma clustering. Oleh karena itu clustering sangat berguna untuk menemukan kelompok yang belum dikenal dalam data. Contoh dari clustering di aplikasi seperti business intelligence, web search, dan security.

Manfaat dari clustering adalah metode segmentasi data yang sangat berguna dalam prediksi atau analisa masalah pengelompokkan tertentu dan dapat mengidentifikasi objek dalam berbagai bidang seperti computer vision dan image processing. Konsep dasar clustering yaitu jika hasil clustering baik akan menghasilkan sebuah tingkat persamaan yang tinggi dalam satu kelas dan tingkat persamaan yang rendah antar kelas. Kesamaan tersebut pengukurannya secara numerik terhadap dua buah objek atau lebih. Dalam clustering memiliki empat tipe data yang pertama variable berskala interval yang kedua variabel biner, yang ketiga variabel nominal ordinal atau rasio, yang keempat variabel dengan tipe lainnya Berikut rumus yang digunakan untuk menghitung Euclidean distance:

Keterangan:

$$
\left.\operatorname{Distance}(\mathrm{p}, \mathrm{q})=\sum_{k}^{n} \mu k|P k-q k| r\right) 1 / r
$$

$\mathrm{n}=$ jumlah record data

$\mathrm{k}=$ urutan field data

$\mathrm{r}=2$

$\mu \mathrm{k}=$ bobot field yang diberikan user

Penelitian ini menggunakan metode K-means karena metode tersebut mempunyai kemampuan pengelompokkan data dalam jumlah yang besar dengan waktu komputasi yang cepat dan efisien.

Algoritma K-Means

1. Tentukan berapa banyak cluster $\mathrm{k}$ dari dataset

2. Tetapkan data $\mathrm{k}$ secara acak menjadi pusat awal lokasi klister 
3. Temukan pusat cluster terdekat untuk masing-masing data, dengan begitu maka masing-masing pusat cluster mempunyai subnet dari dataset, sehingga mewakili bagian dari dataset. Lalu terbentuklah cluster $\mathrm{k}: \mathrm{C} 1, \mathrm{C} 2, \mathrm{C} 3, \ldots . . \mathrm{Ck}$

4. Untuk masing-masing cluster $\mathrm{k}$ menentukan pusat luasan cluster dan memperbarui lokasi dari masing-masing pusat cluster ke nilai baru dari pusat luasan

5. Mengulangi langkah ketiga dan kelima hingga data pada setiap cluster menjadi terpusat atau selesai.

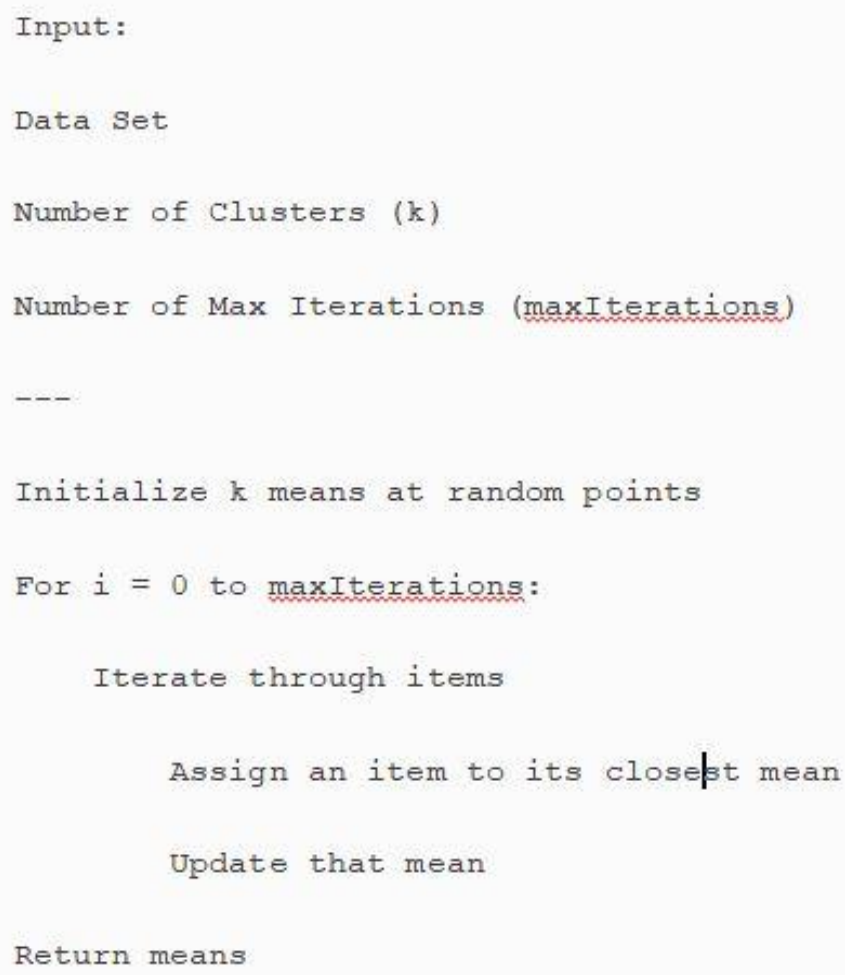

Gambar 3. Pseudo code dari method K-Means

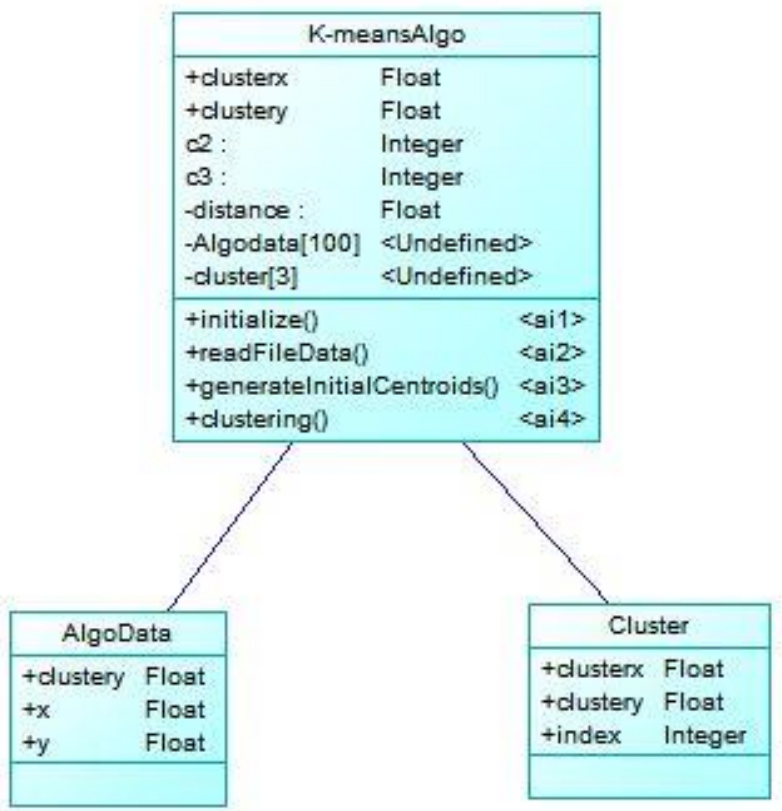

Gambar 4. Class diagram dari metode K-Means 


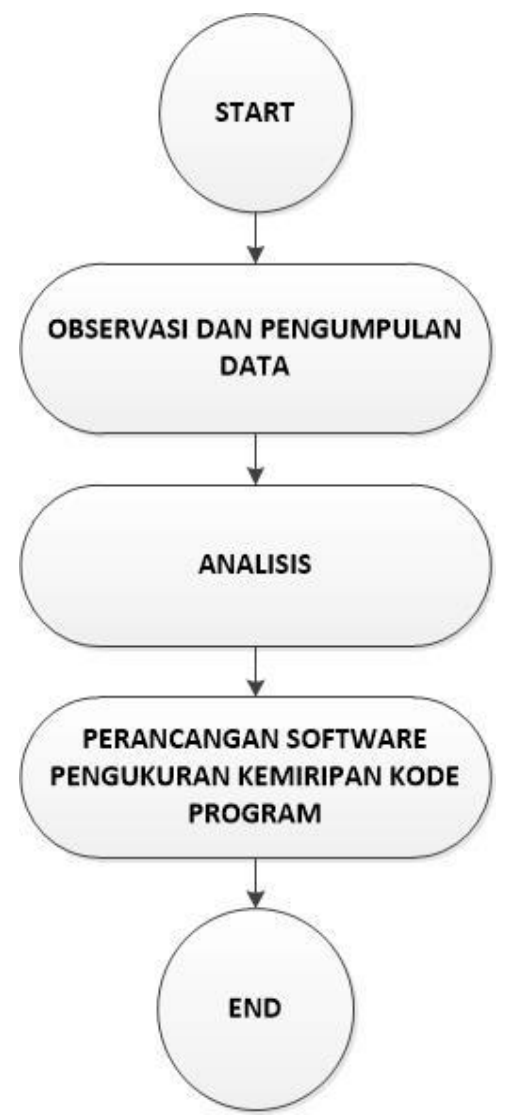

Gambar 5. Alur Penelitian

\section{Observasi dan Pengumpulan Data}

Dalam tahap ini penulis melakukan observasi dan pengumpulan data dengan cara melakukan perbandingan antar aplikasi pendeteksi plagiarisme kode program seperti MOSS. Di dalam aplikasi tersebut memiliki kekurangan yaitu belum ada pengelompokkan data. Di dalam aplikasi MOSS, hanya terdapat plagiarisme saja. Moss (Measure Of Software Similarity) adalah sistem otomatis untuk menentukan kesamaan program. Hingga saat ini, aplikasi utama Moss adalah dalam mendeteksi plagiarisme di kelas pemrograman. Sejak perkembangannya pada tahun 1994, Moss telah sangat efektif dalam peran ini. Algoritma di balik aplikasi Moss adalah peningkatan yang signifikan dibandingkan algoritma deteksi kecurangan lainnya. Bahasa pemrograman pada MOSS : C, C++, Java, C\#, Python, Visual Basic, Javascript, FORTRAN, ML, Haskell, Lisp, Scheme, Pascal, Modula2, Ada, Perl, TCL, Matlab, VHDL, Verilog, Spice, MIPS assembly, a8086 assembly, a8086 assembly, HCL2. MOSS ini menggunakan algoritma Rabin Karp [6].

\begin{tabular}{|c|c|c|c|}
\hline $\begin{array}{l}\text { /home/ubuntu/Projects/work/2015/uct- } \\
\text { csc1010h/tutorials/4/raw/1/1 }\end{array}$ & 口 & $\begin{array}{c}\text { /home/ubuntu/Projects/work/2015/uct- } \\
\text { cse1010h/tutorials/4/raw/4 } /(73 \%)\end{array}$ & $\square$ \\
\hline 4-71 & $\square$ & $2-66$ & 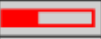 \\
\hline $95-111$ & $\square$ & 90-106 & $\square$ \\
\hline $115-132$ & 문 & $110-127$ & C \\
\hline
\end{tabular}

Gambar 6. Hasil Persentase 
/home/ubuntu/Projects/work/2015/uct-csc1010h/tutorials/4/raw/

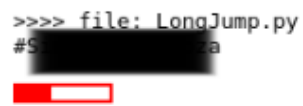

print ("***** Long Jump Information System ******)

print ("Please enter the names of competitors. (Press return when done.)")

print ("Competitor no, 1:")

competitor $=$ input ()

b, c, g, h, d, k = 1, 0, 0,0, [], 0

maxi, competitors - [], [competitor]

while True:

b $+=1$

print ("Competitor no. "+str(b)+" :")

competitor $=$ input ()

if competitor $=n " n:$ break

else:

competitors. append (competitor)

print("Please enter the distances for each competitor.")

for each in competitors:

at1 = input ("Attempt $1: \backslash n "$

at2 $=$ input ( "Attempt $2: \backslash \mathrm{n} ")$

at $3=$ input ( "Attempt $3: \backslash \mathrm{n} ")$

$x=(a t 1+a t 2+a t 3) \cdot$ lower ()

if (at $1+a t 2+a t 3)$. find("oul") $!=-1$ :

d. append (at 1)

d. append (at2)

d. append (at 3 )

maxi.append (max (eval (at1), eval (at2), eval (at3)))

Gambar 7. Kode program pertama

/home/ubuntu/Projects/work/2015/uct-csc1010h/tutorials/4/raw

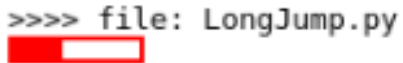

print ("****** Long Jump Information System ******")

print("Please enter the names of competitors. (Press return when done.)")

print("Competitor no. 1:")

competitor $=$ input ()

$b, c, g, h, d, k=1,0, \theta, 0,[], \theta$

maximums, competitors $=[],[$ competitor $]$

while True:

b $+=1$

print ("Competitor no. "+str(b)+":")

competitor = input ()

if competitor $=="$ " break

else:

competitors.append (competitor)

print("Please enter the distances for each competitor.")

for each in competitors:

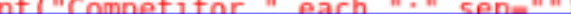

attempt1 = 1nput("Attempt $1:(n ")$

attempt2 = input ("Attempt $2: \backslash n "$ )

attempt3 $=$ input ("Attempt $3: \backslash n ")$

$g=($ attempt $1+$ attempt $2+$ attempt 3$)$. lower ( )

if (attempt1+attempt2+attempt 3 ), find("oul") != -1:

d. append (at tempt1)

d. append (at tempt2)

d. append (attempt3)

maximums , append (max (eval (attempt1) , eval (attempt2) , eval (attempt3))

d. remove ("foul ")

Gambar 8. Kode program kedua 


\section{Analisis}

Pada tahapan ini menganalisa bahwa algoritma pada MOSS yaitu Algoritma Rabin Karp adalah algoritma yang kompleks karena ada beberapa tahapan yang membuat plagiarisme dapat dideteksi dengan tepat dibandingkan dengan algoritma yang lain. Penelitian ini juga menggunakan method $\mathrm{K}$-Means yang berguna untuk pengelompokkan (cluster) data.

\section{Perancangan Software Pengukuran Kemiripan Kode Program}

Dalam tahap ini akan membuat rancangan Software pengukuran kemiripan kode program berdasarkan data yang telah diperoleh dari tahap observasi dan pengumpulan data serta tahap analisa. Perancangan Software ini dibuat sesuai analis yang dibutuhkan. Perancangan Software ini akan memiliki batasan jumlah data yaitu sebanyak 20. Output dari perancangan Software ini adalah cluster dari setiap data.

\section{HASIL DAN PEMBAHASAN}

Ada beberapa langkah dalam penelitian ini, pertama adalah memasukkan data yang akan dicek plagiarismenya. Yang akan menjadi pembandingnya adalah modul koneksi. Pada langkah ini data yang akan dibandingkan dimasukkan ke dalam program tersebut

\section{Algoritma Rabin Karp}

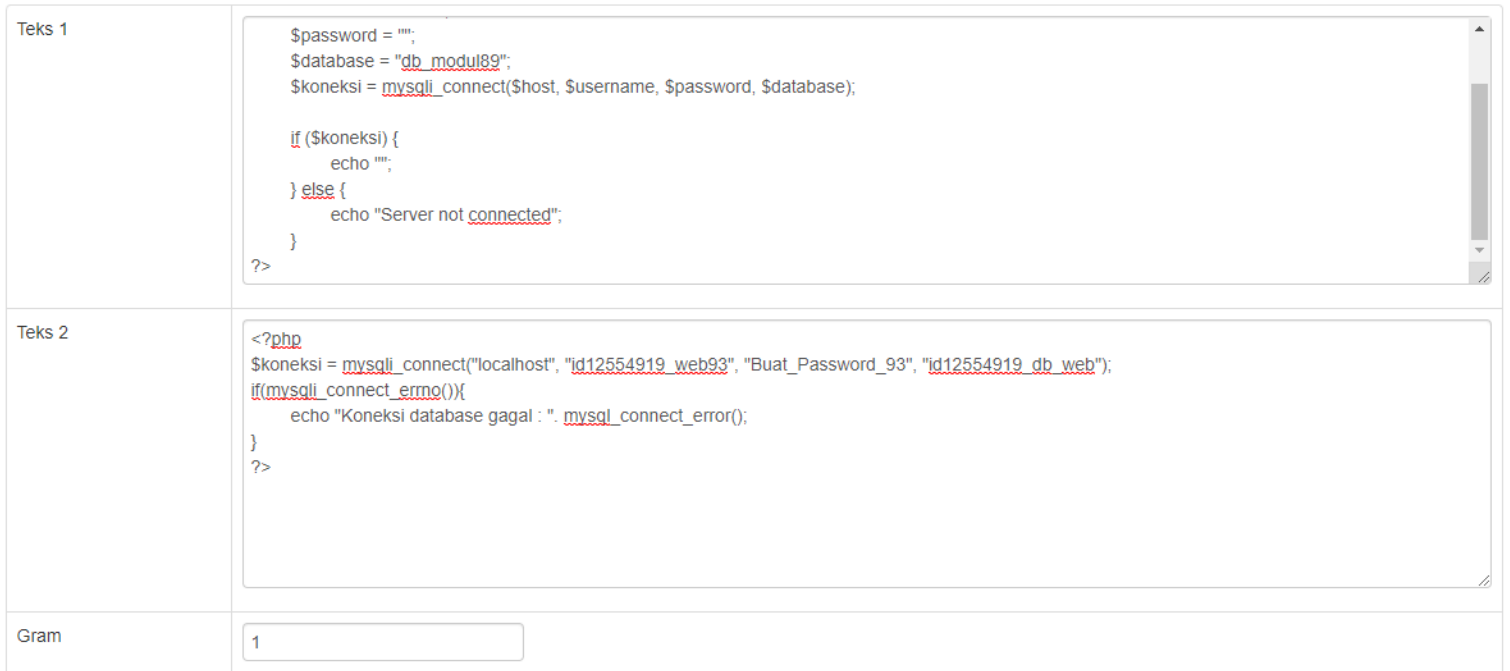

Gambar 9. Contoh algoritma rabin karp

Gram disini berguna untuk membagi kode program ke dalam gram yang ditentukan nilai gramnya. Setelah data masuk, hasil menunjukkan proses White Insensitivity. white insensitivity adalah proses penghilangan tanda huruf dan mengubah teks menjadi kata - kata tanpa huruf kapital. Kemudian proses Hash, pada proses ini, kita menggunakan rumus:

$$
\mathrm{H}\left(\mathrm{c}_{1 \ldots} \ldots \mathrm{c}_{\mathrm{k}}\right)=\left(\mathrm{c}_{1} * \mathrm{~b}^{(\mathrm{k}-1)}+\mathrm{c}_{2} * \mathrm{~b}^{(\mathrm{k}-2)}+\ldots+\mathrm{c}_{(\mathrm{k}-1)} * \mathrm{~b}^{\mathrm{k}}+\mathrm{c}_{\mathrm{k}}\right) \bmod \mathrm{q}
$$

Selanjutnya adalah proses Fingerprint. Jika proses hash sudah berakhir maka akan masuk pada fingerprint. Di dalam proses ini, akan mencari nilai hash yang sama antar 2 kode program. Proses akhir adalah Dice's Similarity Coefficient. Proses tahap akhir ini, menentukan persamaan 2 kode program dengan persamaan Dice's Similarity Coefficient [7]. 
Tabel 3. Pengecekan plagiarisme pada kode program

\begin{tabular}{|c|c|c|}
\hline Proses & Teks 1 & Teks 2 \\
\hline Code & $\begin{array}{l}<\text { ?php } \\
\text { \$koneksi } \\
\text { mysqli_connect("localhost", } \\
\text { "id12554919_web93", } \\
\text { "Buat_Password_93", } \\
\text { "id12554919_db_web"); } \\
\text { if(mysqli_connect_errno())\{ } \\
\text { echo "Koneksi database gagal : ". } \\
\text { mysql_connect_error(); } \\
\text { \} } \\
\text { ?> }\end{array}$ & $\begin{array}{l}\text { <?php } \\
\text { \$host = "localhost"; } \\
\text { \$username = "root"; } \\
\text { \$password = ""; } \\
\text { \$database = "db_modul89"; } \\
\text { \$koneksi = mysqli_connect(\$host, } \\
\text { \$username, } \\
\text { \$database); } \\
\text { if (\$koneksi) \{ } \\
\text { echo ""; } \\
\text { \} else \{ } \\
\text { echo "Server not connected"; } \\
\text { \} } \\
\text { ?> }\end{array}$ \\
\hline white insensitivity & $\begin{array}{lr}\text { lt php } & \text { koneksi mysqliconnect } \\
\text { localhost } & \text { id12554919web93 } \\
\text { buatpasswo } & \text { rd93 } \\
\text { id12554919dbweb } & \text { if } \\
\text { mysqliconnecterrno echo koneksi } \\
\text { database gagal mysqlconnecterror } \\
\text { gt }\end{array}$ & $\begin{array}{l}\text { lt php host localhost username root } \\
\text { password database dbmodul } 89 \\
\text { koneksi mysqliconnect host } \\
\text { username password database if } \\
\text { koneksi echo else echo server not } \\
\text { connected gt }\end{array}$ \\
\hline k-gram & 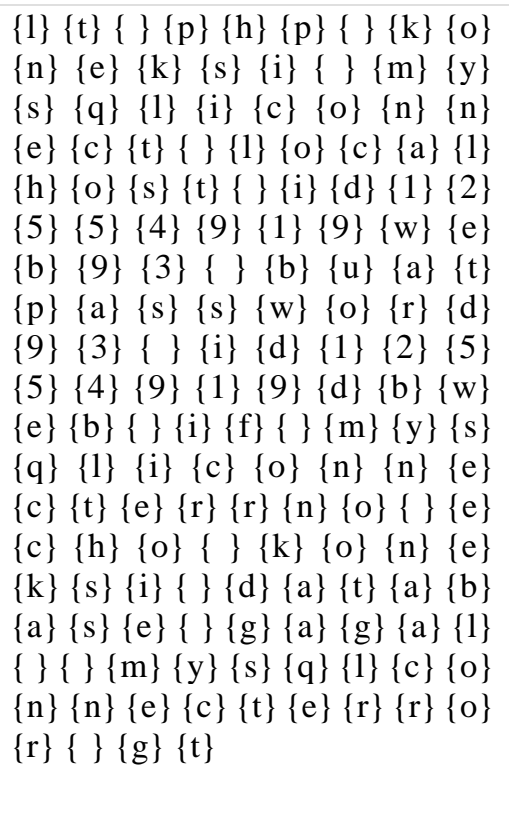 & 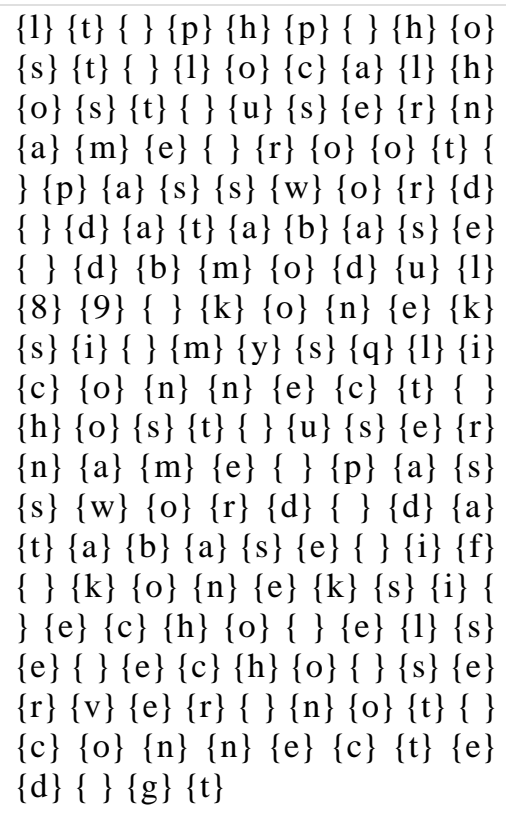 \\
\hline Hash & 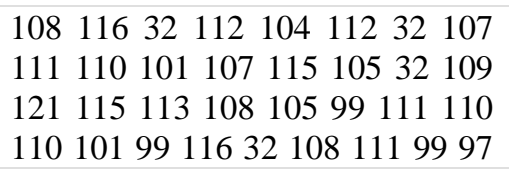 & 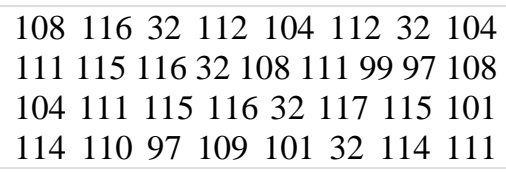 \\
\hline
\end{tabular}




\section{Fingerprint}

Dice's Similarity Coefficient

Tabel 4 adalah tabel setelah di periksa plagiarisme-nya

Tabel 4. Hasil plagiarisme
10810411111511632105100 4950535352574957119101 98575132981179711611297 115115119111114100575132 1051004950535352574957 10098119101983210510232 10912111511310810599111 11011010199116101114114 110111321019910411132107 11111010110711510532100 971169798971151013210397 103971083232109121115113 1089911111011010199116 10111411411111432103116

$1111163211297 \quad 115115119$ 11111410032100971169798 971151013210098109111100 117108565732107111110101 10711510532109121115113 $\begin{array}{llllllll}108 & 105 & 99 & 111 & 110 & 110 & 101 & 99\end{array}$ $\begin{array}{llllllll}116 & 32 & 104 & 111 & 115 & 116 & 32 & 117\end{array}$ 1151011141109710910132 11297115115119111114100 321009711697989711510132 10510232107111110101107 115105321019910411132101 108115101321019910411132 11510111411810111432110 111116329911111011010199 11610110032103116

10811632112104107111110

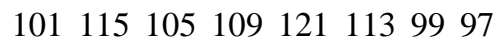
10049505352571199851117 114102103

108116321121041111159997 11710111411010911910098 $\begin{array}{llllllll}56 & 57 & 107 & 105 & 121 & 113 & 102 & 118\end{array}$ 103

10811632112104107111110101115105109121113999710057 11998117114102103

$87.27 \%$

\begin{tabular}{|c|c|c|c|}
\hline$\Delta$ & A & B & C \\
\hline 1 & No & Dokumen & Kemiripan \\
\hline 2 & 1 & 18650027_Diah Rahmadhita_Modul Koneksi & $87,50 \%$ \\
\hline 3 & 2 & 18650055_Lingga Wahyu_Modul Koneksi & $80,50 \%$ \\
\hline 4 & 3 & 18650053_ABD Qohar_Modul Koneksi & $81,00 \%$ \\
\hline 5 & 4 & 18650047_Meganata Adam_Modul Koneksi & $81,50 \%$ \\
\hline 6 & 5 & 18650122_Diaz Rizqi_Modul Login & $70,00 \%$ \\
\hline 7 & 6 & 18650005_Nurul Hidayah_Modul Koneksi & $91,50 \%$ \\
\hline 8 & 7 & 18650007_Febrina Dwi_Modul Login & $67,50 \%$ \\
\hline 9 & 8 & 18650003_Aditya Prasetyo_Modul Koneksi & $87,50 \%$ \\
\hline 10 & 9 & 18650004_Ilham Rafif_Modul Login & $58,00 \%$ \\
\hline 11 & 10 & 18650124_Ukhty Uswatun_Modul Login & $49,00 \%$ \\
\hline 12 & 11 & 18650024_Faradilah Putri_Modul Login & $23,00 \%$ \\
\hline 13 & 12 & 18650089_Riska Anggraini_Modul Login & $18,50 \%$ \\
\hline 14 & 13 & 18650026_Indana Nuril_Modul Koneksi & $90,00 \%$ \\
\hline 15 & 14 & 18650070_Prayudha_Modul Login & $34,00 \%$ \\
\hline 16 & 15 & 18650117_Nadilah_Modul Login & $15,50 \%$ \\
\hline 17 & 16 & 18650073_Nada Filsa_Modul Login & $21,70 \%$ \\
\hline 18 & 17 & 18650023_Berlian Fatimah_Modul Koneksi & $80,00 \%$ \\
\hline 19 & 18 & 18650095_Riswan Ibrahim_Modul Koneksi & $87,27 \%$ \\
\hline 20 & 19 & 18650021_Fatma Indika_Modul Login & $13,00 \%$ \\
\hline 21 & 20 & 18650013 Betty Faizatul Modul Koneksi & $84,00 \%$ \\
\hline
\end{tabular}


Dari data tersebut, dikelompokkan sesuai dengan cluster masing - masing. Penelitian ini menggunakan 2 cluster untuk menentukan data - data dengan keterangan bahwa cluster 1 adalah modul koneksi, cluster 2 adalah modul login. Jika data memiliki kemiripan data dengan data pembanding sebesar $80 \%$ keatas, maka data akan ditaruh kedalam cluster 1 . Sedangkan, jika data memiliki kemiripan data dengan data pembanding sebesar $80 \%$ kebawah, maka data akan ditaruh kedalam cluster 2.

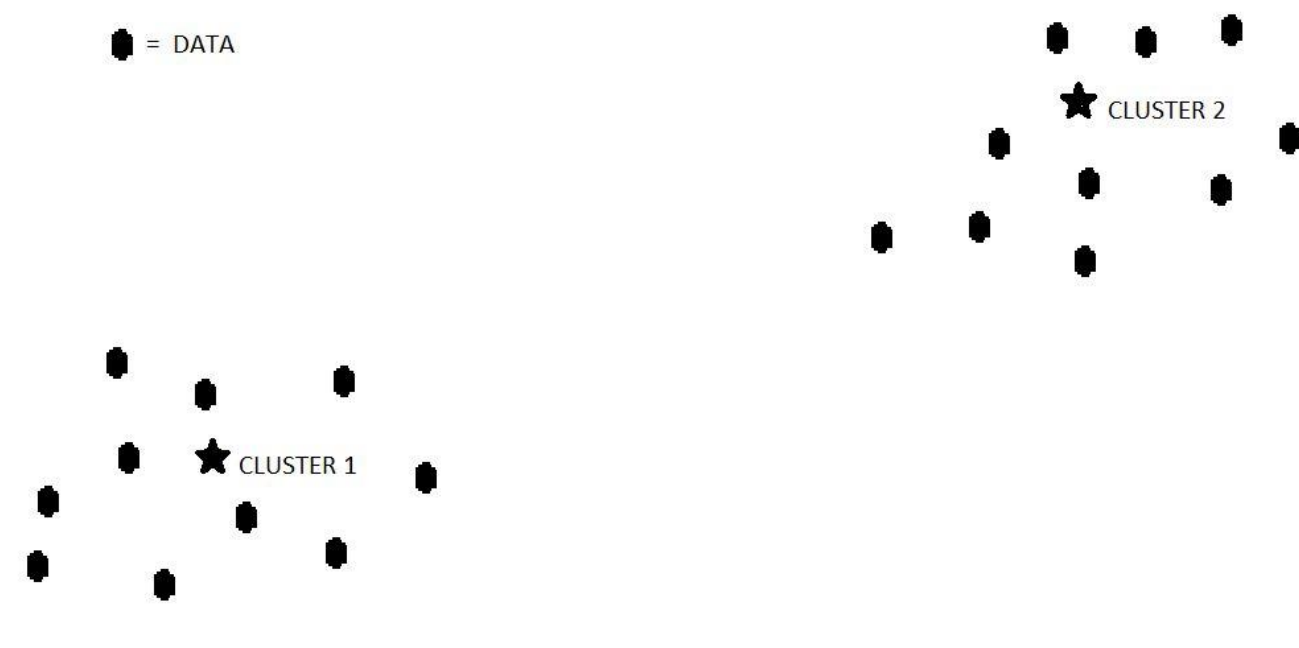

Gambar 10. Penggambaran dari metode K-Means

\section{KESIMPULAN}

Berdasarkan hasil penelitian analisis dan perancangan Software pengukuran kemiripan kode program dapat diambil kesimpulan bahwa dalam pengecekan kemiripan kode program menggunakan algoritma Rabin Karp ini menghasilkan persentase dalam memeriksa plagiarismenya. Setelah diperiksa, data akan dikelompokkan berdasarkan cluster masingmasing. Sehingga data dalam satu kelompok memiliki tingkat kemiripan yang maksimum dan data antar kelompok memiliki kemiripan yang minimum.

\section{REFERENSI}

[1] I. Firmawan, E. Usada, I. F. Adam, S. Informatika, and I. T. Telkom, "RANCANG BANGUN APLIKASI PENDETEKSI PLAGIAT SOURCE CODES DENGAN TOOLS JPLAG ( STUDI KASUS IT TELKOM PURWOKERTO ),” pp. 529-535, 2018.

[2] Y. Dharmayanti and Y. F. A, "PENDETEKSIAN KESAMAAN DOKUMEN MENGGUNAKAN ALGORITMA RKR- GST ( RUNNING KARP RABIN-GREEDY STRING TILING ),” 2011.

[3] J. Priambodo, "Pendeteksian Plagiarisme Menggunakan Algoritma Rabin-Karp dengan Metode Rolling Hash," J. Inform. Univ. Pamulang, vol. 3, no. 1, p. 39, 2018, doi: 10.32493/informatika.v3i1.1518.

[4] S. Schleimer, D. S. Wilkerson, and A. Aiken, "Winnowing: Local Algorithms for Document Fingerprinting," Proc. ACM SIGMOD Int. Conf. Manag. Data, pp. 76-85, 2003.

[5] P. A. R.-K. dan P. P. dengan A. K.-M.-P. Andres, Christopher, and H. Saloko, "Penelaahan Algoritma Rabin-Karp dan Perbandingan Prosesnya dengan Algoritma Knut-Morris-Pratt," 2006, no. m, pp. 1-4.

[6] K. W. Bowyer and L. O. Hall, "Experience using 'MOSS' to detect cheating on programming assignments," Proc. - Front. Educ. Conf., vol. 3, 1999, doi: 10.1109/fie.1999.840376.

[7] Salmuasih and A. Sunyoto, "Implementasi Algoritma Rabin Karp untuk Pedeteksi Plagiat Dokumen Teks Menggunakan Konsep Similarity,” Semin. Nas. Apl. Teknol. Inf., pp. F23-F28, 2013. 